University of Wollongong

Research Online

Faculty of Engineering - Papers (Archive)

Faculty of Engineering and Information

Sciences

October 1996

\title{
Dome-Shaped Space Trusses Formed by Means of Posttensioning
}

G. Dehdashti

University of Bushehr, Iran

L. C. Schmidt

University of Wollongong

Follow this and additional works at: https://ro.uow.edu.au/engpapers

Part of the Engineering Commons

https://ro.uow.edu.au/engpapers/350

\section{Recommended Citation}

Dehdashti, G. and Schmidt, L. C.: Dome-Shaped Space Trusses Formed by Means of Posttensioning 1996. https://ro.uow.edu.au/engpapers/350

Research Online is the open access institutional repository for the University of Wollongong. For further information contact the UOW Library: research-pubs@uow.edu.au 


\title{
Dome-Shaped Space Trusses Formed by Means of PostTensioning
}

\author{
By G. Dehdashti ${ }^{1}$ and L. C. Schmidt, ${ }^{2}$ Member, ASCE
}

\begin{abstract}
Dome-shaped space trusses can be derived from a flat configuration by means of posttensioning. The structure considered here is devised to be a near mechanism initially and during the posttensioning operation. It is a near mechanism as only the flexural stiffness of the continuous top chords provides any resistance to deformation. Therefore, no appreciable force is induced in the members of the structure during the shape formation process. The results of experimental and theoretical work on the shape formation of a dome-shaped space truss by means of posttensioning are presented herein. An analytical procedure that includes both geometric and material nonlinearities is developed to determine the final shape of the dome-shaped space truss, using commercially available finite-element software. The ultimate aim is to lead to significant economies in the construction of large-span lightweight structures by eliminating or minimizing the need for scaffolding and heavy cranes in the shaping and erection of such structures.
\end{abstract}

\section{INTRODUCTION}

Using the existing standardized systems of space frame construction, double-layer grids and braced barrel vaults, which have a developable surface, can be erected by bringing identical elements together without any change in the initial angles between their elements. However, domes, which are not among developable surfaces, cannot be constructed by bringing together elements of the same length without somehow imposing an in-plane shear deformation on their constituent cells, which causes a change in the initial angles between their elements, particularly near the corners if formed from a rectangular surface.

The method of posttensioning space trusses discussed herein, makes it possible to form dome-shaped space trusses of interesting architectural shapes by using members of the same length (Schmidt 1993b; Dehdashti 1994).

\section{BASIC DESIGN OF TEST}

A test was carried out in order to form a gently curved dome-shaped space truss (GCDSST) by means of posttensioning.

A flat single-chorded space truss (SCST) was used as the mechanism to be posttensioned to form the GCDSST. It was basically a rectangular grid mesh (RGM) of $13 \times 13 \times 1.8$ $\mathrm{mm}$ square hollow section (SHS) continuous top chords with $13.5 \times 2.3 \mathrm{~mm}$ circular hollow section (CHS) tubes bolted to it in the form of out of plane pyramidal web units. Initially, shorter edge bottom chords (made of $17 \times 3.2$ CHS seamless tube) were placed all around the perimeter of the model (see Fig. 1). These bottom chords spanned between the apices of the web units, but were inserted too short.

The purpose was to form a surface with positive Gaussian curvature (i.e., a dome) from the originally flat top chord layer. The shape was to be achieved by passing posttensioning wires through the lower edge chords that were too short by a defined amount. The gaps were then closed by posttensioning the wires. It was expected that the largest deformations during posttensioning would occur in the pyramidal units at and

'Lect., Univ. of Bushehr, No. 387 Shahid Heidari St. (14 Meter Lashkar), Nezam Abad-e Shomali, Postal Code: 16369, Tehran, Iran.

'Prof. of Civ. Engrg., Dept. of Civ, and Min. Engrg., Univ. of Wollongong, Northfields Ave., Wollongong, NSW 2522 Australia.

Note. Associate Editor: Louis Geschwindner. Discussion open until March 1, 1997. To extend the closing date one month, a written request must be filed with the ASCE Manager of Journals. The manuscript for this paper was submitted for review and possible publication on February 21,1995 . This paper is part of the Journal of Structural Engineering, Vol. 122, No. 10, October, 1996. CASCE, ISSN 0733-9445/96/0010$1240-1245 / \$ 4.00+\$ .50$ per page. Paper No. 10156.

1240 / JOURNAL OF STRUCTURAL ENGINEERING / OCTOBER 1996 around the corners of the square truss, where the originally orthogonal top chords would form into diamond shapes in their plane.

The length of the edge bottom chords used in the model was $456 \mathrm{~mm}$. This left a gap of $36 \mathrm{~mm}$ in the $x$ - (longer) direction and $26 \mathrm{~mm}$ in the $y$ - (shorter) direction in each bottom chord panel in the flat position before the posttensioning operation closed the gaps. Strain gauges were attached to different members for measuring axial forces and top chord radii of curvature. Fig. 2 shows the experimental model formed into a GCDSST just after posttensioning.

During the shape formation of the model, a posttensioning force of $4.8 \mathrm{kN}$ was applied initially to all four sides of the model. The force was then increased to $8.6 \mathrm{kN}$ until all the edge bottom chords were locked in position. Fig. 3 shows the model GCDSST after posttensioning.

Because the continuous top chords were of the same length in each direction, they had to deform with varying radii of curvature in order to be formed into a dome (i.e., a surface with positive Gaussian curvature). As a result, the top chord surface would appear as shown in Fig. 4 in side elevation.

\section{OBSERVATIONS FROM MEASUREMENTS}

The following points could be observed from measurements made on the gently curved dome-shaped model space truss formed by means of posttensioning from the flat condition.

1. Each of the top chords lies in a plane. The orthogonal central top chords lie in vertical planes. The planes of the other top chords were at an angle to the vertical plane. This angle increased on movement from the middle to the edges of the GCDSST.

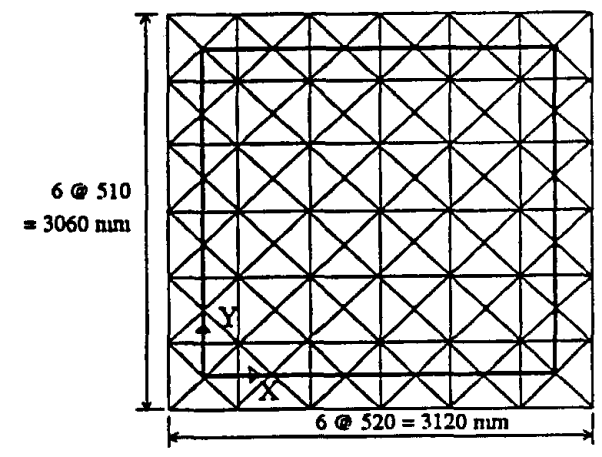

FIG. 1. SCST With Loose Bottom Chords All around to Form Dome 


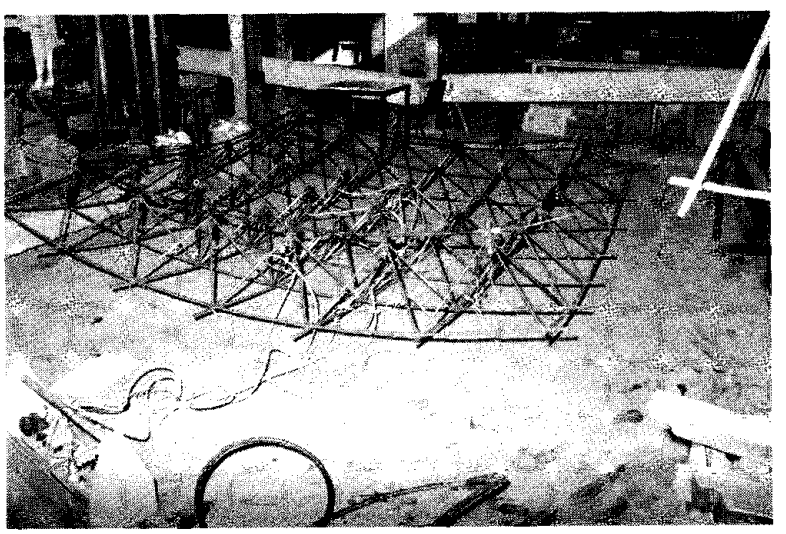

FIG. 2. Model to Be Formed into GCDSST

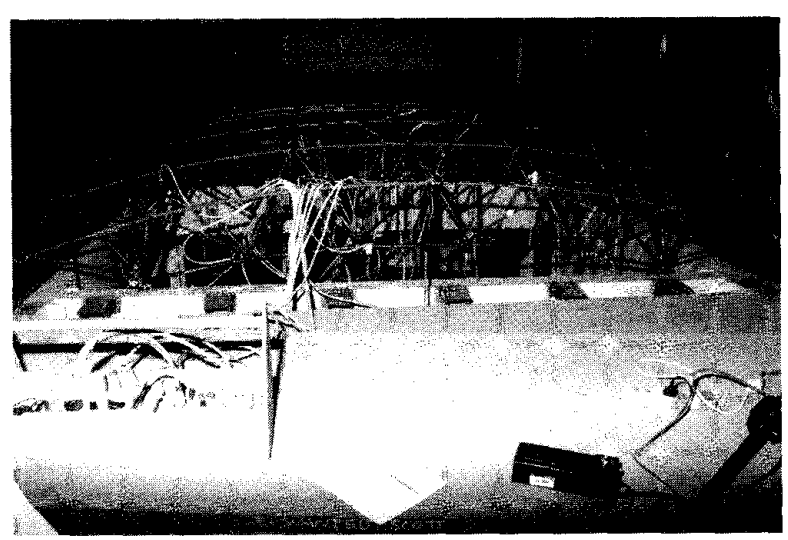

FIG. 3. Model GCDSST after Posttensioning

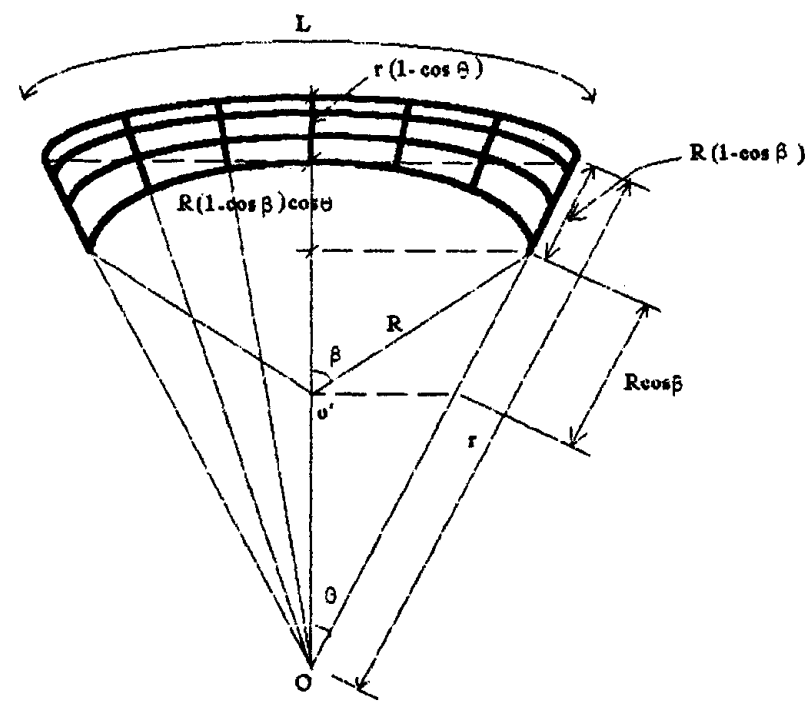

FIG. 4. Geometry of Top Chord Layer in Dome-Shaped Space Truss

2. The center of curvature of each top chord lies at some point between the middle and the edge top chords centers of curvature ( $O$ and $O^{\prime}$ in Fig. 4).

3. The radii of curvature of each of the initially parallel top chords varied from a minimum at the edges to a maximum at the center of the dome-shaped space truss.

4. The whole shape is symmetrical about the centerlines.

\section{DERIVATION OF BASIC GEOMETRICAL RELATIONS FOR TOP CHORD SURFACE}

\section{(Case 1) Top Chords with Equal Lengths in Both Directions (Base Model Has Square Mesh Grid of Top Chords before Posttensioning)}

With regard to the preceding observations, the following relations can be obtained between the half-span subtended angles of the middle and edge top chords and their radii of curvature (see Fig. 4) for a dome-shaped space truss formed by means of posttensioning an originally square SCST.

Because the top chords are equal in length in both directions

$$
r \theta=\frac{L}{2} \Rightarrow R=\frac{\theta}{\beta} r
$$

where $r$ and $\theta=$ radius of curvature and subtended angle of middle top chord; $R$ and $\beta=$ radius of curvature and subtended angle of edge chord, respectively; and $L=$ length of (continuous) top chord, as shown in Fig. 4.

Projecting different lengths on the plane of the middle chord (i.e., the vertical plane) gives the following:

$$
[r-r(1-\cos \theta)-R(1-\cos \beta) \cos \theta] \tan \theta=R \sin \beta \cos \theta
$$

Solving (1) and (2), and after some manipulation, it is found that

$$
1=\frac{\theta}{\beta}\left(1-\cos \beta+\frac{\sin \beta}{\tan \theta}\right)
$$

Solution of (3), with the condition of $\beta>\theta$ or $r>R$, gives $\beta$ $=2 \theta$ (see Fig. 5), using the Mathematica package (Ellis and Lodi 1991). The line $\beta=2 \theta$ (the bold line) in Fig. 5 shows the roots of the equation defining the top chord surface of the posttensioned dome, i.e., (3). Therefore, for a dome-shaped space truss formed by means of posttensioning an originally square SCST, the relation between the radii of curvature and the subtended angles of the edge and middle top chords in the two orthogonal directions reduces to

$$
\beta=2 \theta \text { and } r=2 R
$$

For each design case, once the rise and span of the domeshaped space truss (either at the edges or in the middle) are

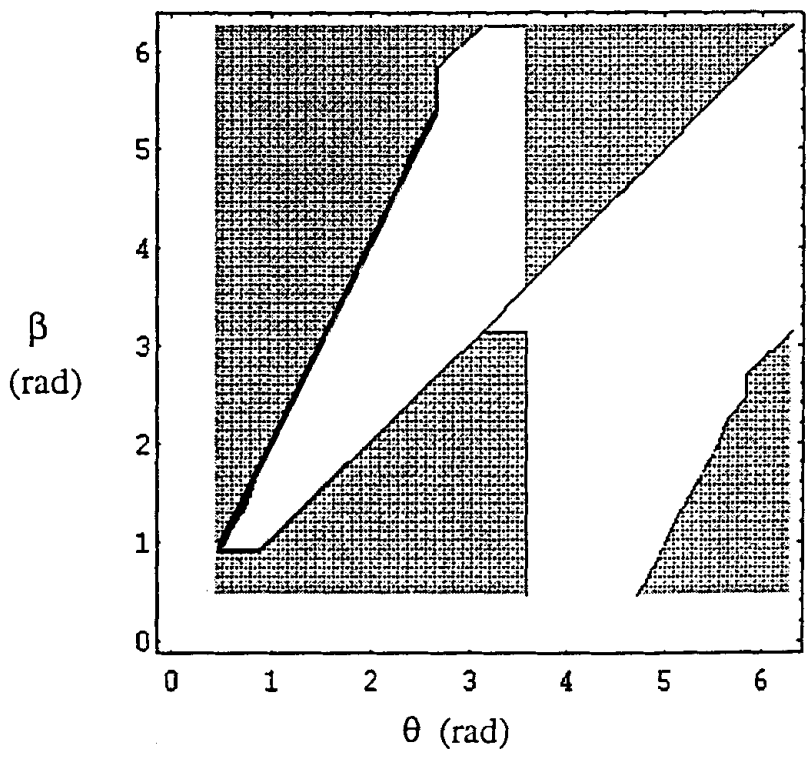

FIG. 5. Contour Plot of Zero Line (i.e., Root) of Eq. (3) 
given, the radius of curvature, the subtended angle, and the length of the top chord can be calculated for the edge or the middle top chord from simple geometrical relations. Then, from (1) and (2), the subtended angle and the radius of curvature for the other (i.e., middle or edge) top chord can be found.

Relations similar to (1) and (2) hold between the subtended angle and the radius of curvature of the middle top chord and the subtended angle and the radius of curvature of the other top chords lying between the middle and the edges of the dome-shaped space truss formed by means of posttensioning. The centers of curvature for all top chords lie on different points along the vertical line passing through the middle of the dome-shaped space truss, with the centers of curvature of the edge and middle chords marking the top and bottom limits on that line, respectively (see Fig. 4).

Despite what might appear at first sight, measurements show that it is not correct to consider a linear change between the two extremes (i.e., the edge and middle top chord radii of curvature) to find the radii of curvature and the subtended angles of the intermediate top chords.

It should be mentioned that for the case of a dome-shaped space truss with equal curvatures and subtended angles in both directions, the formed shape as defined by (4) has an upper limit in terms of the subtended angles $\theta$ and $\beta$. The extreme case is a dome with circular edge top chords $\left(\beta=180^{\circ}\right.$; Fig. 4 ) on the four sides and two orthogonal semicircular middle top chords $\left(\theta=\beta / 2=90^{\circ}\right)$. This case seems, of course, to be a purely geometrical limit, regardless of whether the physical properties of the top chords, webs and joints would allow such a form to be shaped practically or not.

\section{(Case 2) Top Chords with Different Lengths in Two Directions}

In a more general case, the top chord radii of curvature and subtended angles might be different in the two orthogonal directions, either due to the fact that the original gaps in the edge bottom chords may be chosen to be different in the two directions, or due to having different lengths for the top chords in the two orthogonal directions, as was the case for the test model herein which was used to shape the gently curved dome-shaped space trusses (GCDSST).

In such a case, (1) still holds between the top chord radii of curvature and subtended angle for each direction because the lengths of the top chords are identical in each of the separate directions. Therefore, it can be found that (see Fig. 6)

$$
R=\frac{\theta}{\beta} r \quad \text { and } \quad R^{\prime}=\frac{\theta^{\prime}}{\beta^{\prime}} r^{\prime}
$$

If the lengths of the top chords are the same in both directions, i.e., for a case of an originally square SCST, but with different gap lengths in the edge bottom chords in the two directions

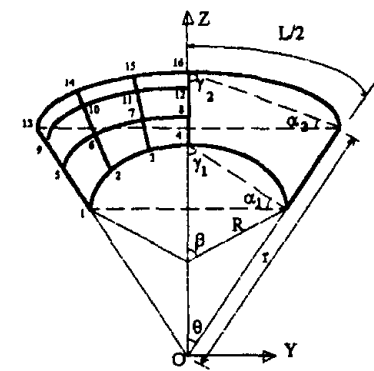

(a)

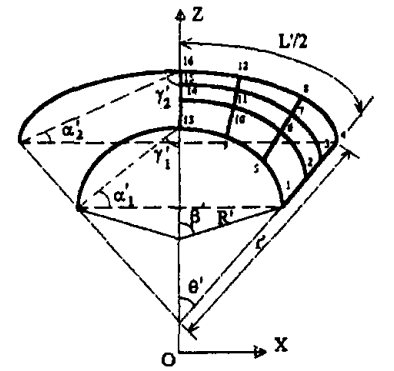

(b)
FIG. 6. Dome Top Chord Radil of Curvature and Subtended Angles in Two Directions

1242 / JOURNAL OF STRUCTURAL ENGINEERING / OCTOBER 1996

$$
\frac{L}{2}=\frac{L^{\prime}}{2} \Rightarrow r \theta=r^{\prime} \theta^{\prime}=R^{\prime} \beta^{\prime}=R \beta
$$

But in a general case, $L \neq L^{\prime}$. Referring to Fig. 6(a)

$$
\left[r-r(1-\cos \theta)-R^{\prime}\left(1-\cos \beta^{\prime}\right) \cos \theta\right] \tan \theta=R \sin \beta \cos \theta^{\prime}
$$

and from Fig. 6(b)

$\left[r^{\prime}-r^{\prime}\left(1-\cos \theta^{\prime}\right)-R(1-\cos \beta) \cos \theta^{\prime}\right] \tan \theta^{\prime}$

$$
=R^{\prime} \sin \beta^{\prime} \cos \theta
$$

The above expressions reduce to

$$
\begin{aligned}
{\left[r-R^{\prime}\left(1-\cos \beta^{\prime}\right)\right] \sin \theta } & =R \sin \beta \cos \theta^{\prime} \\
{\left[r^{\prime}-R(1-\cos \beta)\right] \sin \theta^{\prime} } & =R^{\prime} \sin \beta^{\prime} \cos \theta
\end{aligned}
$$

Eqs. (5), (6), (10), and (11) show the relations between the radii of curvature and the subtended angles of the edge and middle top chords in the two orthogonal directions for domeshaped space trusses formed by means of posttensioning an originally flat single-chorded space truss (SCST).

\section{COMPARISON BETWEEN GEOMETRICAL FORMULA AND MEASUREMENTS}

From measurements made on the gently curved domeshaped model space truss, the edge and middle top chords radii

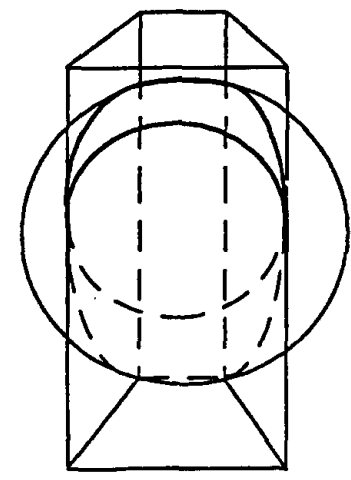

(a)

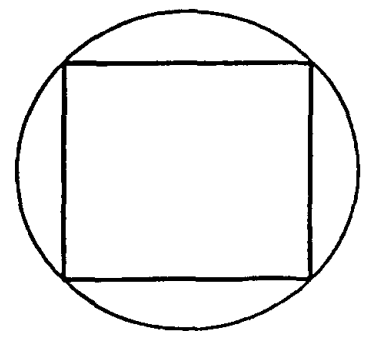

(b)
FIG. 7. Surface Cut from Sphere by Four Vertical Planes: (a) Perspective; (b) Plan View

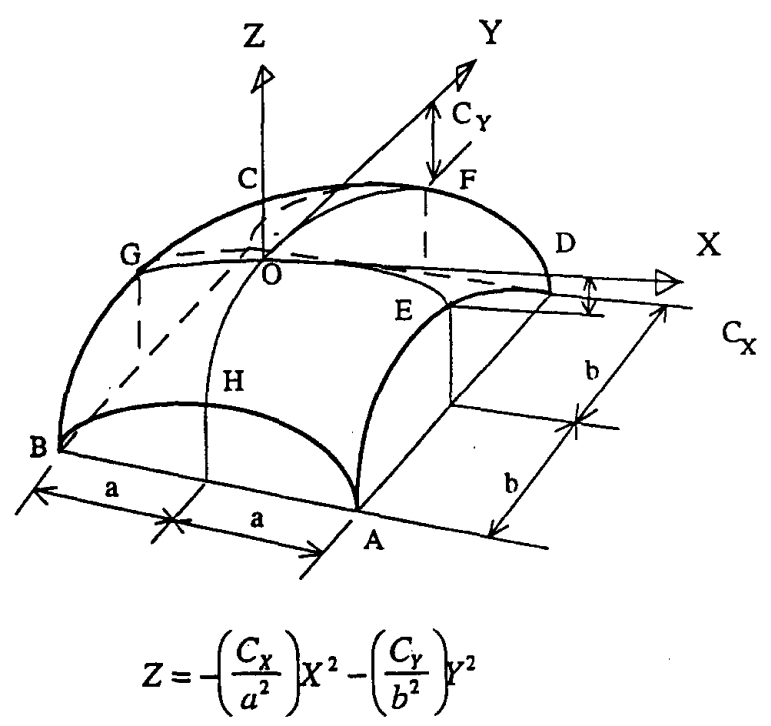

FIG. 8. Elliptic Paraboloidal Surface 


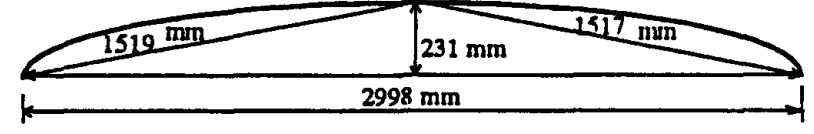

FIG. 9. Measurements on Continuous Edge Top Chord in $y$-DIrection

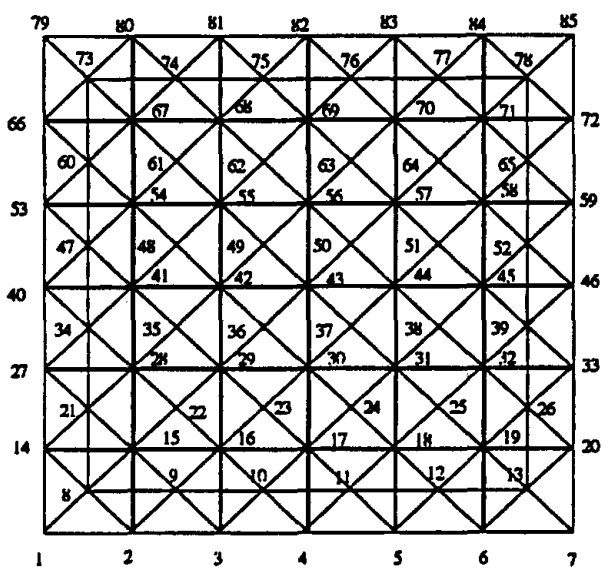

FIG. 10. Model for Nonlinear Shape-Formation Analysis; Node Numbers

of curvature and subtended angles were found (see Fig. 6). Then, the radii of curvature and subtended angles obtained from measurements were substituted in $(5)-(11)$ in order to see whether the measured data fit into the derived geometrical equations or not. The results are given in the following:

$$
\begin{aligned}
& \text { Eq. }(5) \rightarrow 5400 \approx \frac{10.90}{16.23} \times 8043.6=5401.0 \mathrm{~mm} \\
& \text { Eq. }(6) \rightarrow 4723 \approx \frac{13.33}{18.92} \times 6704=4723.3 \mathrm{~mm}
\end{aligned}
$$

Eq. (10): $\left[8043.6-4723\left(1-\cos 18.92^{\circ}\right)\right] \sin 10.90^{\circ} \approx 5400$

$$
\times \sin 16.23^{\circ} \times \cos 13.33^{\circ} \quad \therefore 1472.5 \approx 1468.6 \mathrm{~mm}
$$

Eq. 11: $\left[6704-5400\left(1-\cos 16.23^{\circ}\right)\right] \sin 13.33 \approx 4723$

$$
\times \sin 18.92^{\circ} \times \cos 10.90^{\circ} \quad \therefore 1496.0 \approx 1503.8 \mathrm{~mm}
$$

As observed, the two sets of values are almost equal to each other. Therefore, the results just mentioned show that the derived geometrical equations are in reasonable agreement with the measured data, i.e., with the radii of curvature and subtended angles of the middle and edge top chords of the GCDSST.

Eqs. (5)-(11) show that there are eight unknowns required to define the shape of the center and edge top chords of the posttensioned dome-shaped space truss. Given the rise and span in the two orthogonal directions elimination of four of the unknowns follows; the remaining unknowns can be found from these four equations.

Therefore, for the original design of the geometry of a dome-shaped space truss formed by means of the posttensioning method described herein, depending upon the desired rise and span of the edge top chords, the gaps in the edge bottom chords of the original SCST can be proportioned by assuming the edge top and bottom chords to be approximately in the same plane, and consequently, the final rise and span of the central top chords can be found from (5) $-(11)$.

\section{COMPARATIVE STUDY OF SHAPE}

Despite what might appear at first, the dome-shaped space truss formed by means of posttensioning of the edges is not part of a sphere. If it is assumed that the continuous top chords lie on a surface cut from a sphere by four vertical planes (see Fig. 7), and that each top chord is a circular arc lying in a vertical plane, then in such a case the radii of curvature of the top chords will vary (i.e., decrease from the middle towards the edges), the lengths of the top chords will not be equal and the centers of curvature will lie on two horizontal lines perpendicular to each other. This situation is in contrast to that

TABLE 1. Nodal Coordinates of One-Quarter of GCDSST (See Fig. 10)

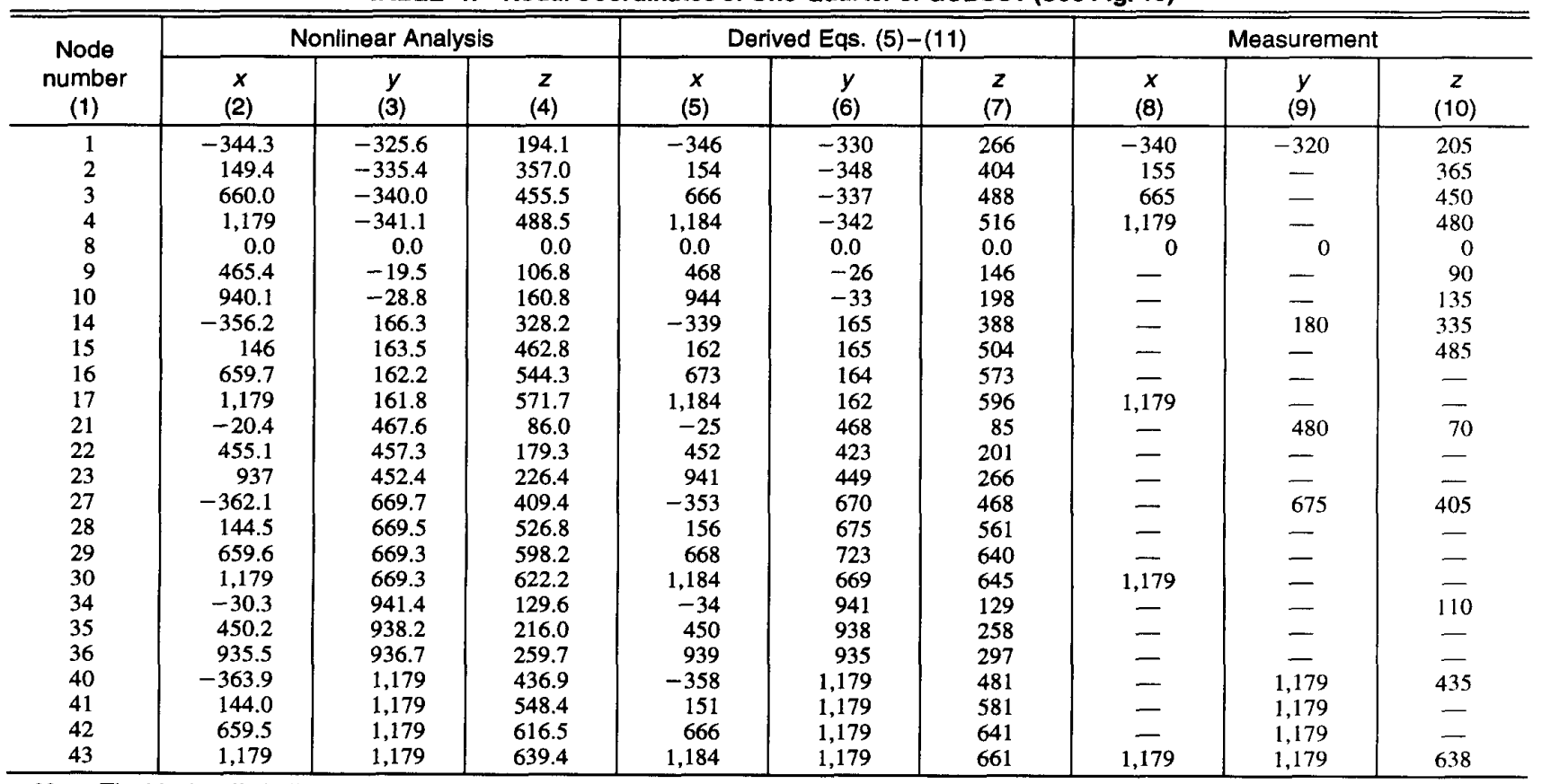

Note: The blank cells indicate that there was no measured data available for those locations. 
of the (gently curved) posttensioned self-erected dome, where the top chords have equal lengths and their centers of curvature lie on a vertical line passing through the center of the dome, although all of the top chords do have circular arcs and varying radii of curvature (which also decrease from the center towards the edges). Therefore, as compared with a spherical surface bounded by four vertical planes (Fig. 7), the top chords of the GCDSST lie in planes at an angle to the vertical (see Fig. 4) and have equal curved lengths in each direction.

Eqs. (5)-(11) define the center and edges of the top chord surface of the posttensioned dome-shaped space truss with good accuracy. However, for practical purposes, especially for the generation of nodes defining the geometry of the model for finite element analysis, an attempt was made to approximate the surface by other means or formula, in order to avoid the tedious calculation of the coordinates of each top chord node by finding its relevant radius of curvature and subtended angle.

The equation of an elpar (i.e., elliptic paraboloid; Fig. 8) was found to provide a fair estimate of the nodal coordinates in a case when the dome has large radii of curvature in the two orthogonal directions, i.e., for a gently curved domeshaped space truss (Schmidt and Dehdashti 1993a). Nevertheless, the elpar formula is inaccurate for the corner nodes of the GCDSST, though it gives accurate results for the center top chord nodes and the center nodes along the edges.

Measurements carried out on the test truss showed that for each continuous top chord, the diagonal distances from the

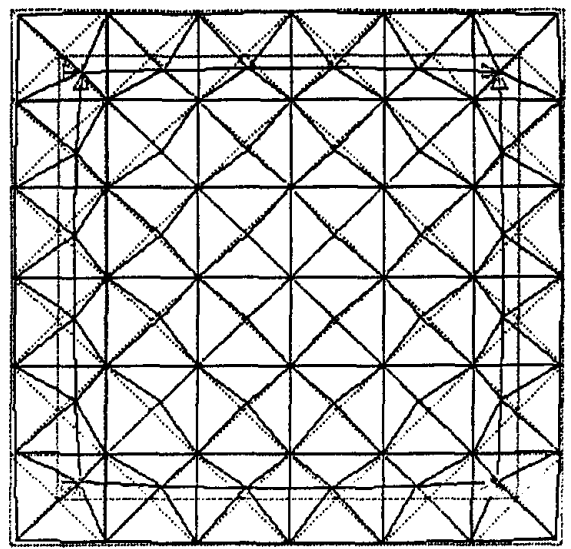

(a)

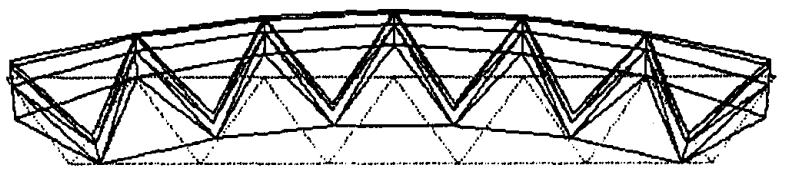

(b)

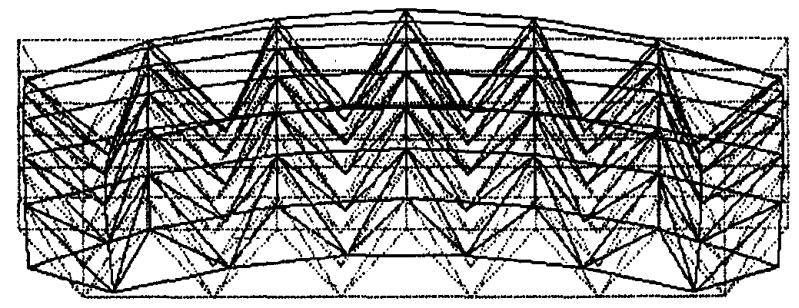

(c)

FIG. 11. GCDSST after Shape Formation Analysis: (a) Plan Vlew; (b) Slde Vlew; (c) Perspective Vlew

1244 / JOURNAL OF STRUCTURAL ENGINEERING / OCTOBER 1996 center to the ends were effectively equal (see Fig. 9). This indicated that the curved shape of the top chords was fairly symmetrical after posttensioning.

It was also observed that the diagonal distances between the center and the ends of the top chords were almost equal for all of the top chords in each direction, with a maximum variation of $5 \mathrm{~mm}$ from the edges towards the centers. This diagonal distance (see Fig. 9) was about $1,520 \mathrm{~mm}$ in the shorter $(y-)$ direction and $1,540 \mathrm{~mm}$ in the longer $(x-)$ direction. This agreement was due to the gentle curvature of the top chords, and that was why the surface could be approximated by an elliptic paraboloid as a result of the sliding (i.e., translation) of a gently curved parabola [which approximates a circular arc (Gould 1988) over another gently curved parabola].

\section{SHAPE FORMATION BY MEANS OF NONLINEAR ANALYSIS}

A nonlinear analysis was performed to generate the shape of the GCDSST. First, the geometry of the model in the flat position was input with 456-mm-long gap bars all around the model. Then, each corner bottom node of the model was subjected to forced displacements of an absolute value of $120 \mathrm{~mm}$ in the $x$-direction and $96 \mathrm{~mm}$ in the $y$-direction. The length of the shortened bars and the final span of the corner nodes in $x$ and $y$-directions were equal to the values measured on the physical model. The solution method adopted was a full Newton-Raphson method updating the stiffness matrix in each iteration in order to account for both material and geometric nonlinearities. Fig. 10 shows the plan view of the GCDSST with node numbers. The nodal coordinates of the GCDSST, as resulted from the nonlinear shape-formation analysis, are given in Table 1 which also shows the nodal coordinates based on measurements and the geometrical calculations described earlier. Fig. 11 shows different views of the model after the shape formation analysis.

Table 1 shows good agreement between the measured nodal coordinates and both of the computer generated (by means of the nonlinear analysis) and geometrically calculated nodal coordinates. The $z$-coordinates of the nonlinear results are closer to the measured values.

\section{TOP CHORD RADII OF CURVATURE}

Table 2 shows a comparison of the radii of curvature of the top chords of the GCDSST, as obtained from geometrical calculations, overall measurements on the models, and strain gauges. Table 2 shows that, overall, the radii of curvature derived from strain gauge data were larger than those obtained from overall geometrical measurement of the span/rise ratios of the top chords and the calculations.

\section{FURTHER OBSERVATIONS ON TOP CHORD LAYER}

In the shape formation of the GCDSST model by means of posttensioning, on movement from the center towards the

TABLE 2. Top Chord Radil of Curvature ( $\mathrm{mm}$ )

\begin{tabular}{l|c|c|c}
\hline \multicolumn{1}{c|}{$\begin{array}{c}\text { Chord location } \\
\text { (1) }\end{array}$} & $\begin{array}{c}\text { Calculated } \\
(2)\end{array}$ & $\begin{array}{c}\text { Measured } \\
(3)\end{array}$ & $\begin{array}{c}\text { Strain } \\
\text { gauge } \\
(4)\end{array}$ \\
\hline Middle chord in $x$-direction & 6,704 & 6,704 & 7,674 \\
Middle chord in y-direction & 8,044 & 8,044 & 9,497 \\
Edge chord in $x$-direction & 4,723 & 4,723 & - \\
Edge chord in $y$-direction & 5,400 & 5,400 & - \\
Next to middle (x-direction) & 6,411 & - & 7,270 \\
Next to middle (y-direction) & 7,610 & - & 9,362 \\
Next to edge (x-direction) & 5,681 & - & - \\
\hline
\end{tabular}

Note: The blank cells indicate that there was no data available either from overall measurement or from strain gauging. 


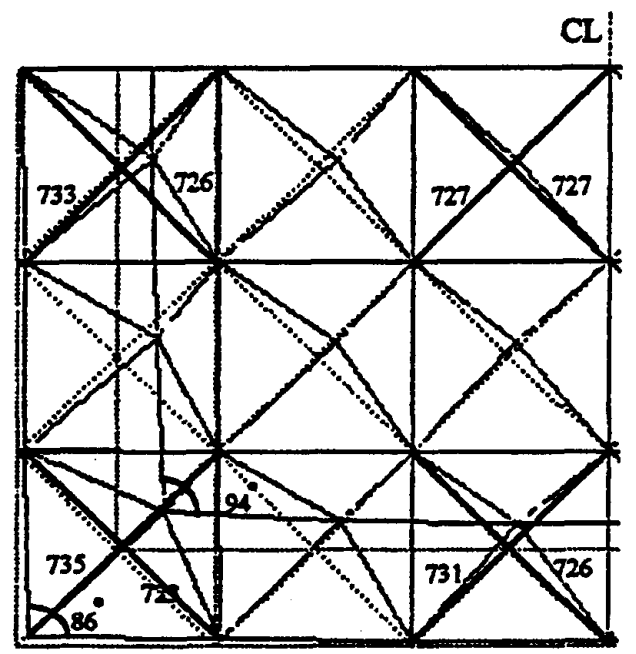

FIG. 12. GCDSST's Top Chord Layer Deformation Due to Posttensioning

edges, and on movement from the center of each edge towards the corners, the originally equal diagonals of each rectangular cell changed in length, reaching their maximum difference at the corners. The rectangular cells took up diamond shapes as required for the in-plane shear deformation of a nondevelopable surface.

For the GCDSST model, the original diagonal length of each top chord cell was equal to $728 \mathrm{~mm}$. Measurements showed that for the top chord cells just next to the central top chord node, both diagonal lengths were $727 \mathrm{~mm}$. These lengths changed to $726 \mathrm{~mm}$ and $731 \mathrm{~mm}$ in the center of the shorter ( $y$-direction) edge and to $726 \mathrm{~mm}$ and $733 \mathrm{~mm}$ in the middle of the longer ( $x$-direction) edge. The diagonals of the corner diamond-shaped cells were $723 \mathrm{~mm}$ and $735 \mathrm{~mm}$ (see Fig. 12).

Also, as shown in Fig. 12, there was a $4^{\circ}$ reduction in the originally square angle between the orthogonal top chords at the corners of the GCDSST model after posttensioning. There was a corresponding, but reverse change in the angle between the orthogonal edge bottom chords at the corners; the angle increased to $94^{\circ}$.

\section{CONCLUSIONS}

It has been shown that it is possible to shape a singlechorded flat space truss into a surface with positive Gaussian curvature, i.e., a dome-shaped space truss. By this curving process, the structure can be considered to be self-erecting. This process holds potential for significant economies in the fabri- cation and erection of large-span space structures by eliminating the need for scaffolding and large cranes.

In forming the gently curved model dome, it was observed that the design shape could be formed from a planar base model of a single-chorded space truss with mean errors of $0.7 \%, 1.4 \%$, and $6 \%$ for the nodal coordinates in the $x$-, $y$-, and $z$-directions, respectively, as compared with the computerbased shape-formation predictions.

The procedure developed for the determination of the shapeformation, or self-erection, of a dome-shaped space truss, formed by means of the posttensioning method described herein, made use of commercially available finite-element software (e.g., ANSYS). The analytical method used included both material and geometric nonlinearities, but did not include the eccentricities of the chord members at joints. The members were assumed to be pin-ended. The nonlinear analysis gave good results in terms of nodal displacements for the shape formation when compared with the experimental measurements. The nonlinear analysis allowed modeling of the behavior of the bottom chords with original gaps and of the prestressing wire with freedom of movement inside the bottom chord tubes.

\section{ACKNOWLEDGMENTS}

The first writer wishes to thank the Iranian Ministry of Culture and Higher Education for a PhD scholarship provided to him during this research. Financial support was also provided for this research by the Australian Research Council, and is gratefully acknowledged.

\section{APPENDIXI. REFERENCES}

Dehdashti, G. (1994). "Shape formation and ultimate load behaviour of post-tensioned space trusses," $\mathrm{PhD}$ thesis, Univ. of Wollongong, Wollongong, Australia.

Ellis, W., and Lodi, E. (1991). A tutorial introduction to mathematica. Books/Cole Publishing Co., Calif.

Gould, P. L. (1988). Analysis of shells and plates. Springer-Verlag, New York, N.Y.

Schmidt, L. C., and Dehdashti, G. (1993a). "Curved space trusses formed from single-chorded planar space trusses." ACMSM 13: Proc., 13th Australasian Conf. on the Mech. of Struct. and Materials, L. C. Schmidt, ed., Univ. of Wollongong, Australia.

Schmidt, L. C., and Dehdashti, G. (1993b). "Shape creation and erection of metal structures by means of post-tensioning." Space structures 4 : Proc., 4th Int. Conf. on Space Struct., H. Nooshin, ed., Thomas Telford, London, England.

\section{APPENDIX II. NOTATION}

The following symbols are used in this paper:

$L=$ length of continuous top chord;

$R$ = edge top chord radius of curvature;

$r=$ center top chord radius of curvature;

$\beta=$ edge chord subtended angle;

$\theta=$ middle chord subtended angle; and

$\rho=$ radius of curvature. 